Original research article

\title{
The psychological burden experienced by paediatric nurses during children's hospital care
}

\author{
Nikoletta Páll 1,2,3*, Erzsébet Gorove ${ }^{3}$, Ildikó Baji ${ }^{4}$ \\ ${ }^{1}$ Semmelweis University, Faculty of Health Science, Department of Nursing, Budapest, Hungary \\ 2 Semmelweis University, School of Ph.D. Studies, Budapest, Hungary \\ ${ }^{3}$ Péterfy Hospital-Polyclinic and Jenő Manninger National Traumatology Institution, Budapest, Hungary \\ ${ }^{4}$ Semmelweis University, Faculty of Health Science, Department of Applied Psychology, Budapest, Hungary
}

\begin{abstract}
Working with children requires a great deal of attention and patience from a nurse, and it is also vital to emphasise the enormous amount of responsibility that accompanies this profession. Events related to children involve more stress, possibly causing an increased level of psychological burden for nurses, which, if unprocessed, may lead to symptoms of secondary traumatisation that may result in burnout.

Within the framework of this research, we investigated the psychological demands on nurses working in paediatrics. Our goal was to learn the opinions and activities of paediatric nurses in connection with the psychological preparation and support of children and their parents, a subject previously not analysed in Hungary. In the light of the results of the research, our further goal is to prove the need to adapt the system of care that has become internationally pervasive with proven positive effects (Child life specialist).

A descriptive and multivariate analysis was carried out relying on the results of online quantitative questionnaires filled in by members of the Chamber of Hungarian Healthcare Professionals (Paediatric Department).

The responses of the 361 paediatric nurses who filled in our questionnaire show that children's psychological preparation was mainly carried out by nurses. However, the increased workload prohibited them from meeting children's and parents' emotional needs. When caring for patients, nurses often found themselves in situations where they were not able to react to a child's psychological needs. They find their work so mentally demanding that it has an influence on their private life as well.

Children's emotional state greatly influences nurses, which is why the presence of a specialist who is able to prepare children for interventions and provide emotional support to them and their families is needed in hospital care. Besides all these factors, providing psychological support is also necessary when carrying out nursing roles.
\end{abstract}

Keywords: Child; Child care; Emotional work; Nurse; Secondary traumatisation

\begin{abstract}
Abbreviations:
ANOVA - analysis of variance; BSc - Bachelor of Science; CLS - Child life specialist; ICU - Intensive care unit; IES-R - Impact of Event Scale-Revised; MESZK - Chamber of Hungarian Healthcare Professionals; MSc - Master of Science; $p$ - probability; PFCC - Patientand family-centered care; PTSD - Posttraumatic stress disorder; REC - Research Ethics Committee; SPSS - Statistical Package for the Social Sciences; Std - Standard deviation; STS - Secondary traumatic stress; STSS - Secondary Traumatic Stress Scale; TUKEB - Medical Research Council, National Scientific and Research Ethics Committee
\end{abstract}

\section{Introduction}

In the course of treating children, the consideration of psychological aspects is of paramount importance. A sick child is more susceptible to the effects of stress since the physical and mental strain make him or her more sensitive compared to his or her healthy counterparts (Slifer, 2014). A change in the usual environment may be a source of stress for children, which is reinforced by the fact that infants have a lower level of coping strategy (Hárdi, 1995; Lerwick, 2013). Pain and anxiety are interrelated: in other words, a child's feeling of anxiety aggravates his feeling of pain and pain increases anxiety ( $\mathrm{He}$ et al., 2015). Children requiring in-hospital acute treatment often cry not only because of pain, but also because they are scared. The nature of nurses' work inevitably elicits an emotional reaction in nurses, making the nursing staff more tense and distracting them during an intervention (Martin, 2017). Some of the most important conditions of nursing are the emotional work, the emotional attention, the empathic care given to a child and his or her family. Working with children in a critical state is a particularly demanding situation in terms of emotions; therefore, nurses working in this field require a larger degree of emotional support (Fülöp et al., 2016). If they are not provided this support, it can lead to emotional exhaustion which may be a significant factor in the subsequent de-

\footnotetext{
* Corresponding author: Nikoletta Páll, Semmelweis University, Faculty of Health Science, Department of Nursing, Üllői út 26, 1085 Budapest, Hungary; e-mail: pall.nikoletta@se-etk.hu http://doi.org/10.32725/kont.2021.025

Submitted: 2021-01-27 • Accepted: 2021-05-24 • Prepublished online: 2021-05-28 
velopment of burnout (Fülöp et al., 2011; Lombardo and Eyre, 2011; Sabo, 2011).

Healthcare professionals themselves can be traumatised during patient care, that is to say, secondary traumatic stress can develop, which is an emotional and behavioural disorder. This is caused by learning of a traumatic event experienced by another person that can be explained by transmission processes, empathy and emotional contagion (Beck, 2011; Elwood, et al., 2011). Events related to children entail a higher stress level; therefore, secondary traumatisation is greater in paediatric nurses (also the risk of Secondary Traumatic Stress (STS): their STS level is higher compared to the population and to other nurses caring for adults) (Czaja et al., 2012).

Our research, carried out in 2013, examined the impact on paediatric nurses of working with traumatised children. The study consisted of questionnaires given to nurses working at five different paediatric surgery and trauma departments (90 respondents), and as the control group to nurses working in general wards (at departments that do not involve increased mental strain, e.g. no critically ill children or no child deaths). We investigated professional assistance, emotional work and processing thereof, as well as secondary traumatisation. Significant differences were found, whereby nurses working in paediatric surgery and trauma wards felt their work to be more mentally demanding, compared to the control group. According to $82.2 \%$ of nurses, children's mental state influenced their work, and nearly the whole sample claimed that children's mental support would be essential and that they consider the permanent presence of a psychologist or a supporting specialist to be necessary on these wards. Nurses working in paediatric surgery and trauma departments encounter cases when they are unable to respond properly to a child's mental reactions, which they said is also stressful for them. In their view, the events at the hospital affect their family life and their behaviour at home. We also examined the extent of secondary traumatisation. As regards to the total scale and sub-scales (emotional intrusion, avoidance, hyperarousal) of the STSS (Secondary Traumatic Stress Scale - STSS), higher values were shown at paediatric surgery wards (Bride et al., 2004; Páll and Fülöp, 2013).

In a US study, Berger et al. (2015) examined 239 paediatric nurses working for emergency care units and surgical departments. Compassion fatigue was high, at $71.5 \%$ of participants, $29 \%$ reported burnout and $27 \%$ of respondents also showed high STSS values. The responses revealed that nurses also apply several coping techniques, for instance prayer, and some nurses found it important to take part in their patients' funerals.

The extent of post-traumatic stress disorder (PTSD) was analysed by Czaja et al. (2012) with the help of questionnaires for paediatric nurses working in acute wards (173 respondents). $21 \%$ of nurses showed high PTSD values, and nurses with significant PTSD symptoms also showed the symptoms of anxiety and depression.

According to a questionnaire survey among nurses (115 persons) working in pediatric intensive care units, Bursch et al. (2018) found that $24 \%$ of nurses showed PTSD, $20 \%$ anxiety, and 30\% depression symptoms; younger and less experienced nurses scored higher on anxiety.

With the help of interviews, Hilliard and O'Neill (2010) assessed the emotional work of paediatric nurses who worked with children suffering from burns at an Irish hospital. Participants recognised the need for treating children's and parents' emotional reactions, where nurses also find it difficult to react appropriately. In this study, what caused serious anxiety for nurses was that the heavy workload limited them from meeting the emotional needs of children and parents.

Nurses' psychological preparation and support in relation to interventions have positive effects on child patients and result in fewer negative situations for nurses who are responsible for the care. Abroad, child life specialists (CLSs - highly qualified medical specialists in the field of paediatrics) provide support to children and their families in the hospital stay process, in various psychological support situations and in bereavement, if need be. They prepare children for interventions according to their age with the help of different games and stories, and apply various distraction techniques (e.g. blowing bubbles, storytelling or rocking of infants) during interventions (Boles et al., 2020, da Silva et al., 2017; Zhang et al., 2015). They also provide a great deal of help for the healthcare team as a prepared child is much calmer and interventions are easier and faster to perform. The work of the CLS has been proven to have a beneficial effect on the nurses' work as well. Nurses consider the preparation for interventions and distracting techniques to be most useful, which they are unable to provide to all children without the presence of a CLS for lack of knowledge and time. Besides, paediatric nurses feel that they are able to concentrate on the given intervention much better with the help of a CLS (Drayton et al., 2019). The presence of the family and involvement of parents in nursing duties are a natural phenomenon at most paediatric wards these days. An increasing number of studies deal with the concept, implementation and effects of PFCC (Patient- and Family-Centered Care) at an international level (Mendess, 2016). Thus, the emotional state of both the child and the family can affect the work of paediatric nurses. The work of a CLS is also helpful for parents. Research has shown that parents assess the work of the CLS positively: in their opinion, it was extremely helpful for them during hospital stays (LeBlanc et al., 2014).

In Hungary, child life specialists are not available, so nurses are also tasked with children's psychological preparation and providing support to their family members, which is often emotionally straining for them.

Our general aim was to carry out a survey among paediatric nurses that investigates nurses' psychological burden in connection with the psychological preparation and emotional support of children and their parents. Using the results thereof we can make recommendations for the development of the Hungarian adaptation of the CLS care system with its proven positive effects, which includes its placement in the care structure and the levels and fields of education to obtain the related competences.

\section{Materials and methods}

\section{Sampling procedure}

The TUKEB examined the research plan that we submitted and granted the professional ethical licence under number ETT TUKEB 31352-3/2019/EKU.

The electronic questionnaire applied for our survey was created with the help of the Google application specifically designed for the programming of online questionnaires. The questionnaire was sent to paediatric nurses with the help of the Chamber of Hungarian Healthcare Professionals (MESZK), sent to the personal e-mail addresses of subscribers to the newsletter, and the Chamber also published it on its website. Within the system of online questionnaires, the exact email addresses are not visible, so we were able to ensure anonymity. Our questionnaire was also published on the Facebook site 
called "Tankórterem". Data collection started on 1st July 2019 and ended on 31st January 2020, during which 361 nurses filled in the online version. All questionnaires received during the survey period were assessable.

\section{Measuring instrument}

Paediatric nurses questionnaire

The independently created questionnaire consisted of 62 questions: I. Consent to the research (3 questions), II. Socio-demographic questions (8 questions), III. Questions related to the emotional work and professional support in the hospital (26 questions), IV. Questions in connection with the processing of emotional burden by paediatric nurses (24 questions). The questionnaire contained 42 closed-ended and 11 open-ended questions and 9 questions with a five-point Likert scale. The assessment of socio-demographic data entailed participants' gender, age, marital status, highest professional qualification, place of work, profile of the field of paediatric care and the number of years spent there. With the help of questions connected to the emotional work and professional support at the hospital, we surveyed the average number of days that children spent in hospital and the frequency of parents' presence, as well as how children's mental state influenced nurses' work. Further questions looked at what kind of preparation children received before interventions during their hospital stay, how nurses evaluated the importance of this, who carried out the preparation and using what tools, and if preparation is absent, what the possible causes thereof could be. Questions on the processing of the emotional burdens of paediatric nurses examined cases that caused difficulties for nurses and the ways in which they were processed.

\section{Impact of Events Scale (IES-R)}

We used the Hungarian version (Perczel-Forintos et al., 2018) of the Impact of Events Scale, which measures the frequency of phenomena describing subjective stress caused by a traumatic event on a 5-point Likert scale rated between 0-4 endpoints (where 0 means not typical at all and 4 means characteristic all the time). A higher value signified a higher level of subjective distress in connection with a negative event. Its subscales included emotional intrusion, avoidance and arousal. Nurses had to recall the effects of a recent negative event that occurred during their work with child patients.

\section{Secondary Traumatic Stress Scale (STSS)}

The Secondary Traumatic Stress Scale (STSS) developed by Bride et al. (2004.) was applied in our research, the Hungarian version of which was first used in research in Hungary by Fülöp et al. (2011). The questionnaire investigates the work experience in relation to patients who suffered from severe trauma. The questionnaire contains 17 statements, and respondents must decide on a (5-point) Likert scale how characteristic the given sentence was recently in their own cases. A total score can be obtained from the points marked by the respondent that shows the severity of symptoms of secondary traumatisation (<28: none, 28-37: slight, 38-43: medium, 44-48: high, $>$ 49: very high) (Elwood et al., 2011). On the other hand, we can examine each scale, such as the frequency of thought and emotional intrusion, avoidance and signs of arousal (Fülöp et al., 2011).

\section{Data processing and data analysis}

The processing and analysis of data was carried out with the help of the SPSS 25.0 statistic software package (IBM Corporation, Armonk, NY, the United States of America). During the analysis, we examined the relative frequency distribution of the answers to each question, and in the case of the formed indices, their descriptive statistics.

Before the analysis, the STSS complete scale and subscales and the sub-scales of the IES-R had been transformed per sub-scale $\log (x+1)$ in order to normalise their distribution. A comparison of the IES-R sub-scales and that of the STSS total scales and sub-scales was carried out with the help of a correlation matrix in which the Pearson correlation coefficient was calculated to compare the variables of each scale and every sub-scale in pairs $(r=+0,5-1$ : strong positive correlation, $r=+0.0-0.5$ : moderately strong positive correlation).

The effect of certain factors considered relevant on the values of the full scale of the STSS and the IES-R sub-scales was examined using ANOVA.

The analysis of the additional questions was tested by ordinal regression. For those questions where more than one answer could be marked, we used a $\chi^{2}$ (Chi-square) test by analyzing contingency tables. The significance level was set to $p<0.05$ in every case.

\section{Results}

\section{Socio-demographic results}

The demographic indicators related to nurses is shown in Table 1.

Table 1. The distribution of socio-demographic parameters regarding nurses ( $n=361$ nurses)

Gender: female: 355 (98.3\%), male: 6 (1.7\%)

Age: mean: 40.37, SD: 11.222 Min.:18, Max.: 66

\begin{tabular}{lrr} 
Highest educational qualification & & \\
\hline Advanced practice registered nurse (MSc) & 14 nurses & $3.88 \%$ \\
\hline Registered nurse (BSc) & 69 nurses & $19.11 \%$ \\
\hline Licensed nurse & 273 nurses & $75.62 \%$ \\
Auxiliary nurse & 5 nurses & $1.38 \%$
\end{tabular}

How long have you worked as a paediatric nurse? Mean: 17.94, SD: 12.839, Min.: 1, Max.: 45

\begin{tabular}{lll} 
Marital status & & \\
\hline Single & 114 nurses & $31.6 \%$ \\
Partnership & 247 nurses & $68.4 \%$
\end{tabular}

Number of children:

Mean: 1.23, SD: 1.222, Min.: 0, Max.: 12

What area do you work in?

\begin{tabular}{lcc}
\hline & Participants & Percentage \\
\hline General surgery & 12 & 3.3 \\
\hline Internal medicine & 162 & 44.9 \\
Infant care ward & 20 & 5.5 \\
\hline Intensive care unit & 60 & 16.6 \\
\hline Oncology & 30 & 8.3 \\
Psychiatry & 7 & 1.9 \\
\hline Surgery and Trauma & 49 & 13.6 \\
\hline Emergency ward & 19 & 5.3 \\
Other & 2 & 0.6 \\
\hline
\end{tabular}




\section{Data related to children's care}

On the basis of nurses' responses, children spent (on average) 6.45 days as in-patients in their institutions (SD: 8.652, Min.: 0, Max.: 70). Their experience was that $29.6 \%$ of parents (107) were at their children's side during every intervention, while $62.3 \%$ of them (225 parents) were there only partially and $8 \%$ (29 parents) were unable to stay with their children. On a 5-point scale, nurses evaluated with an average of 4.13 (SD: 4.13) how much mental strain the hospital stay placed on the children, according to nurses. We found a significant correlation in this issue, with nurses saying shorter care times put more psychological strain on children $(p=0.033) .96 .4 \%$ of nurses thought that children's mental state affects their work with them. 95 respondents held that when a child is scared and cries, their work is much harder, so nearly all respondents found children's psychological preparation and support to be of great importance.

On a scale of 1 to 5 , the implementation of child-friendly care in the nurses' department averaged 4.15 (SD: 0.871), which showed a correlation with the frequency of preparation of children $(p=0.001)$. Nurses assessed the importance of psychological preparation before interventions appropriate to the child's level of intellect on the same scale, which they assessed with a nearly maximum score (Mean: 4.86 SD: 0.448), and they estimated the frequency of children's preparation at their department to be an average of 4.38 (SD: 0.896). Their experience shows that after preparation fear is reduced, children are more cooperative and behave calmer during interventions. The preparation that, on average, lasted between 1 and 10 minutes, was mostly performed by nurses (according to 222 respondents). More than half of the participants used no tools for the preparation, or maybe just one piece for explaining a specific intervention (e.g. toys, books or a piece of equipment applied in the course of the intervention). According to 241 paediatric nurses, preparation is not performed regularly due to a lack of time - or the parent does it instead of them. Parental presence had a positive effect on the frequency of preparation $(p=0.000)$.

In nurses' view (measured on a 5-point scale), it was evaluated with an average of 4.03 (SD: 1.155) how useful the presence of a specialist would be who would prepare children and their parents for interventions professionally and playfully (appropriate to the child's level of intellect). Nurses working in the surgical and trauma, oncology, intensive care and internal medicine departments found the presence of such a specialist significantly more useful $(p=0.001)$ than in other departments. In their opinion, the occurrence of negative situations could be decreased during children's hospital stays, thereby placing less of a mental strain on nurses.

214 respondents felt that children and their parents were provided with information appropriate to their age and level of intellect, and that children's anxiety and objecting reactions were handled appropriate to their age and level of intellect (evaluated on a 5-point scale, Mean: 4.09, SD: 0.789).

To sum up, on average, nurses assessed children's psychological preparation at 3.78 on a 5-point scale (SD: 0.745 ), which showed significant correlation with the assessment of information provided to child patients appropriate to their level of intellect $(p=0.000)$.

\section{Data related to nurses' emotional strain}

On a 5-point scale, paediatric nurses evaluated with an average of 3.52 (SD: 1.060) how demanding their work was emotionally. Significantly higher values could be seen $(p=0.000)$ at oncology wards, surgery and trauma departments, as well as intensive care units. The average number of days that children had to spend in hospital significantly influenced nurses' assessment of their own psychological burden, a shorter period of hospital care showed a higher value $(p=0.000)$. Nurses who held that children were more stressed by the hospital care, also assessed their own work as being more mentally strenuous $(p=0.000)$.

334 participants (92.5\%) experienced negative events while caring for children that taxed them mentally, and 186 persons $(51.5 \%)$ got into situations during their work when they were unable to respond to children's mental reactions. Regarding these events, different fields were examined separately in order to observe how emotionally demanding the work was on the given ward (Table 2).

Most of these cases stemmed from questions by children with cancer who asked about their own death, but nurses also mentioned situations involving children who were aggressive, abused, and who had lost a parent in an accident. A significant correlation could be observed; nurses who had a negative experience during patient care considered their work to be more mentally taxing $(p=0.001) .85 \%$ of nurses would like to take

Table 2. Negative situations in regard to paediatric fields

\begin{tabular}{|c|c|c|c|c|c|}
\hline \multirow[b]{2}{*}{ Department } & \multirow[t]{2}{*}{$\begin{array}{l}\text { Number of } \\
\text { respondents in total } \\
\text { (persons) }\end{array}$} & \multicolumn{2}{|c|}{$\begin{array}{l}\text { Have you ever had any psychologically } \\
\text { straining experiences? } \\
\text { (persons) }\end{array}$} & \multicolumn{2}{|c|}{$\begin{array}{l}\text { Have you ever experienced any situations } \\
\text { when you were unable to respond to a child's } \\
\text { mental reactions? } \\
\text { (persons) }\end{array}$} \\
\hline & & Yes & No & Yes & No \\
\hline General surgery & 12 & 12 & 0 & 8 & 4 \\
\hline Internal medicine & 162 & 150 & 12 & 90 & 72 \\
\hline Infant care ward & 20 & 17 & 3 & 5 & 15 \\
\hline Intensive care unit & 60 & 58 & 2 & 38 & 22 \\
\hline Oncology & 30 & 29 & 1 & 22 & 8 \\
\hline Psychiatry & 7 & 7 & 0 & 6 & 1 \\
\hline Surgery and trauma & 49 & 42 & 7 & 31 & 18 \\
\hline Emergency ward & 19 & 17 & 2 & 8 & 11 \\
\hline Other & 2 & 2 & 0 & 2 & 0 \\
\hline
\end{tabular}


part in further training on this subject matter; they consider case discussions, practice-oriented, and situational trainings most helpful.

On a 5-point scale, nurses rated the psychological support in their department as moderate (Mean: 3.20 SD: 1.158), and $61.5 \%$ of them consider a permanent psychologist in the ward necessary.

301 nurses ( $84.48 \%$ ) discuss severe cases with family members and 149 with colleagues. 142 nurses would require and 122 nurses would partially like help to process difficult cases in the form of case discussions or one-on-one consultations.

151 paediatric nurses (41.8\%) talk about what happened at their workplace at home often and 192 (53.2\%) rarely. According to 264 nurses (73.1\%), events at their workplace affect the atmosphere of their homes and their behaviour towards their family members; they are more anxious, irritated, exhausted and impatient after these frustrating happenings.

\section{Results of the Impact of Event Scale-Revised (IES-R) and the Secondary Traumatic Stress Scale (STSS)}

With regards to the Impact of Event Scale-Revised (IES-R), nurses had to recall the effects of a recent negative event that occurred during their work with child patients. The Secondary Traumatic Stress Scale (STSS) investigates the work experience in relation to patients who suffered from severe trauma.

Before the analysis, the STSS complete scale and subscales and the sub-scales of the IES-R had been transformed per sub-scale $\log (\mathrm{x}+1)$ in order to normalise their distribution. The results of their scores are shown in Table 3 . The average, minimum and maximum values of the sub-scales of the STSS showed higher scores than those of the IES-R. With regards to the average values of the sub-scales of the STSS, memory intrusion showed the highest number.

Table 3. The values of the subscales of the STSS and IES-R

\begin{tabular}{|c|c|c|c|c|c|c|c|}
\hline & $\begin{array}{l}\text { STSS } \\
\text { total }\end{array}$ & $\begin{array}{c}\text { STSS } \\
\text { intrusion }\end{array}$ & $\begin{array}{c}\text { STSS } \\
\text { avoidance }\end{array}$ & $\begin{array}{c}\text { STSS } \\
\text { arousal }\end{array}$ & $\begin{array}{c}\text { IES-R } \\
\text { intrusion }\end{array}$ & $\begin{array}{c}\text { IES-R } \\
\text { avoidance }\end{array}$ & $\begin{array}{c}\text { IES-R } \\
\text { arousal }\end{array}$ \\
\hline Mean & 3.41 & 2.28 & 2.55 & 2.25 & 0.66 & 0.67 & 0.46 \\
\hline SD Deviation & 0.328 & 0.324 & 0.332 & 0.342 & 0.387 & 0.386 & 0.361 \\
\hline Minimum & 3 & 2 & 2 & 2 & 0 & 0 & 0 \\
\hline Maximum & 4 & 3 & 4 & 3 & 2 & 2 & 2 \\
\hline
\end{tabular}

Significant correlation was found between the values of the total scale and sub-scales of the STSS and those of the subscales of the IES-R as well as some questions of the questionnaires. These results can be seen in Table 4 .

Higher values could be seen for nurses who had less work experience. Correlation could be seen whereby higher values were observed in all scales for those nurses who felt their work to be more stressful, they encountered upsetting cases and experienced situations where they were unable to respond properly to a child's mental reactions in their care duties and workplace events affect their family relationships.

\section{Table 4. Comparison of the total STSS scale and of IES-R subscales with the questionnaire questions}

\begin{tabular}{|c|c|c|c|c|}
\hline Questionnaire questions & $\begin{array}{l}\text { STSS } \\
\text { total }\end{array}$ & $\begin{array}{c}\text { IES-R } \\
\text { intrusion }\end{array}$ & $\begin{array}{l}\text { IES-R } \\
\text { avoidance }\end{array}$ & $\begin{array}{c}\text { IES-R } \\
\text { arousal }\end{array}$ \\
\hline & \multicolumn{4}{|c|}{$p$} \\
\hline How long have you been working as a paediatric nurse? & $0.000^{*}$ & $0.000^{*}$ & $0.000^{*}$ & $0.000^{*}$ \\
\hline How stressful do you consider your work to be? & $0.000^{*}$ & $0.000^{*}$ & $0.012^{*}$ & $0.000^{*}$ \\
\hline How do you see the professional support provided at your ward? & 0.395 & 0.076 & $0.015^{*}$ & $0.010^{*}$ \\
\hline What department do you work at? & $\begin{array}{c}0.001^{*} \\
\text { (for Oncology, ICU, Surgery } \\
\text { and Trauma) }\end{array}$ & 0.131 & 0.352 & 0.072 \\
\hline $\begin{array}{l}\text { Have you ever experienced any negative events in paediatric care } \\
\text { that caused psychological distress? }\end{array}$ & $0.000^{*}$ & $0.000^{*}$ & $0.000^{*}$ & $0.000^{*}$ \\
\hline $\begin{array}{l}\text { Have you ever got into situations when you were unable to } \\
\text { respond to a child's mental reaction? }\end{array}$ & $0.000^{*}$ & $0.000^{*}$ & $0.000^{*}$ & $0.000^{*}$ \\
\hline What kind of cases do you consider to be the most demanding? & $\begin{array}{c}0.004^{*} \text { (a severely injured } \\
\text { child), } \\
0.018^{*} \text { (a child with } \\
\text { a tumour) }\end{array}$ & $\begin{array}{c}0.044^{*} \\
\text { (a dying child) }\end{array}$ & 0.200 & $\begin{array}{l}0.006^{*} \text { (a severely } \\
\text { injured child) }\end{array}$ \\
\hline $\begin{array}{l}\text { Do events at the workplace influence your behaviour with your } \\
\text { family members? }\end{array}$ & $0.000^{*}$ & $0.000^{*}$ & $0.001^{*}$ & $0.000^{*}$ \\
\hline
\end{tabular}


A comparison of the IES-R sub-scales and that of the STSS total scales and subscales was carried out with the help of a correlation matrix in which the Pearson correlation coefficient was calculated to compare the variables of each scale and every subscale in pairs (Table 5 ).

\begin{tabular}{|c|c|c|c|c|}
\hline & $\begin{array}{l}\text { STSS } \\
\text { total }\end{array}$ & $\begin{array}{c}\text { STSS } \\
\text { intrusion }\end{array}$ & $\begin{array}{c}\text { STSS } \\
\text { avoidance }\end{array}$ & $\begin{array}{c}\text { STSS } \\
\text { arousal }\end{array}$ \\
\hline IES- $R$ intrusion & $0.611^{*}$ & $0.591^{*}$ & $0.553^{*}$ & $0.553^{*}$ \\
\hline IES-R avoidance & $0.476^{* *}$ & $0.438^{* *}$ & $0.440^{* *}$ & $0.442^{* *}$ \\
\hline IES-R arousal & $0.649^{*}$ & $0.593^{*}$ & $0.592^{*}$ & $0.626^{*}$ \\
\hline
\end{tabular}

\section{Discussion}

In our study, we examined the psychological burden of nurses working in Hungarian paediatrics $(n=361)$ in connection with children's psychological preparation. We chose the method of an electronic, self-administered questionnaire, which had the advantage of allowing us to obtain data on a widespread scale from different parts of the country.

Nurses' psychological strain depends on the children's and their parents' emotional state as well, so patients' psychological preparation and mental support also have a significant effect on the amount of emotional exhaustion affecting nurses. Following this base hypothesis, our research also examined the psychological preparation and support provided to children in Hungarian hospitals.

According to data regarding paediatric care, on average, children spent 6.45 days in hospital, and in most cases, parents were only able to stay with their children occasionally.

According to nurses, most of the time, hospital care places psychological strain on children, especially in cases when the period of hospital treatment is shorter. Nurses found children's mental support and their psychological preparation for interventions essential, since all these factors also affect their nursing duties. In Hungary, preparation for interventions is mainly carried out by nurses and it takes 10 minutes at the most. In the nurses' view, the reason for this is lack of time. Our figures correspond to the data collected by Hiliard and O'Neill (2010), where nurses stated that the intense workload limited them from meeting the emotional needs of children and parents. According to nurses, the presence of a person in their department would be useful for preparing children for interventions (both professionally and playfully) and also for providing support to parents as well. Nurses working in surgical and trauma departments, oncology, intensive care and internal medicine found the presence of such a specialist significantly more useful. In the nurses' opinion, the presence of a CLS could have a positive effect on their work, since children would be calmer during their hospital stay and fewer negative situations would also occur.

The figures in connection with nurses' emotional work show that nurses working in the above-mentioned departments found their work to be more demanding; they more often encounter cases that they find emotionally taxing and are unable to respond properly to children's psychological reac- tions. All these factors showed a tight correlation with the total scale of the STSS and with all three groups of symptoms of the IES-R (including thought intrusion, avoidance and arousal symptoms). Nurses assessed the psychological support provided at departments to be moderate and they consider the permanent presence of a psychologist to be essential. In addition, they would like further training in which they can acquire skills that will help them and their patients in these situations.

In those cases where nurses considered the hospital care to be more taxing on the child, they felt nurses' work also to be more emotionally demanding, which shows the empathy of the nurses. Relying on the findings of this study, a large section of nurses would like help to process difficult cases in the form of case discussions or one-on-one consultations. Most nurses talk about workplace events at home and try to process more difficult cases that way, which in turn leads to workplace events affecting the atmosphere of their homes and their behaviour towards their family members.

The mean of the STSS values was higher than that of the IES-R. We found a strong and moderately strong positive relationship between the STSS and IES-R sub-scales, suggesting that anxiety in negative situations may be the basis for subsequent secondary traumatisation.

On average, the highest among the STSS sub-scales was avoidance, which may indicate avoidance of thoughts and feelings related to the event. The second highest sub-scale was thought and emotional intrusion, which could mean that nurses often think of their patients - which might have an effect on other nurses as well.

Corresponding to the results of the survey carried out by Bursch et al. (2018), the STSS and IES-R values were higher in participants who had less work experience. Secondary traumatisation or IES-R values were higher in nurses who rated their workplace emotional strain higher and felt that workplace events had an impact on their behavior with their families.

\section{Conclusions}

During hospital treatments, the psychological support of children, parents and nurses is essential, although it is currently not implemented in the Hungarian healthcare system. We hypothesize that labour shortages and the growing number of patients per nurse do not allow for the psychological support of patients and their families, and additionally enhance nurses' emotional exhaustion. The work of a CLS could reduce nurses' psychological burden and would provide support for children and parents as well. In addition, all nurses should be provided with assistance to help process workplace events so that they do not affect family relationships.

\section{Financial support}

EFOP-3.6.3-VEKOP-16-2017-00009, the development of scientific workshops of the Medical, Healthcare and Pharmaceutical Studies.

\section{Division of labour among authors}

NP: Planning of the study, creation of the measuring instrument, obtaining permissions, research of literature, database management, statistical analysis, wording of the manuscript. EG: Management of the database and statistical analyses. IB: The professional appraisal of the manuscript. The final version of the article was read through and approved by all the authors. 
Ethical aspects and conflict of interests

The authors have no conflict of interests to disclose.

\section{Acknowledgements}

We would like to express our gratitude to all parents who voluntarily took part in our research.

\section{Psychická zátěž dětských zdravotních sester při péči o děti v nemocnici}

\section{Souhrn}

Práce s dětmi vyžaduje od zdravotní sestry velkou dávku pozornosti a trpělivosti a je také nezbytné zdůraznit obrovskou míru odpovědnosti, která tuto profesi provází. Zdravotní události spojené s dětmi s sebou nesou větší míru stresu, což může způsobovat zvýšenou míru psychické zátěže sester, která - pokud s ní není dále pracováno - může vést k příznakům sekundární traumatizace, jež může vyústit ve vyhoření.

V rámci tohoto výzkumu jsme zkoumali psychologické nároky kladené na zdravotní sestry pracující v pediatrickém oboru. Naším cílem bylo poznat názory a aktivity dětských sester v souvislosti s psychologickou přípravou a podporou dětí a jejich rodičů, což je téma, které dosud nebylo v Mad'arsku analyzováno. Ve světle výsledků výzkumu je naším dalším cílem prokázat potřebu zavést systém péče, který se stal mezinárodně rozšíreným, s prokázanými pozitivními účinky (role Child life specialist).

Byla provedena deskriptivní a multivariační analýza opírající se o výsledky z kvantitativních online dotazníků vyplněných členy Komory mad'arských zdravotníků (pediatrická sekce).

Z odpovědí 361 dětských zdravotních sester, které vyplnily náš dotazník, vyplývá, že psychologickou přípravu dětí prováděly především sestry. Vysoká pracovní zátěž jim však bránila v uspokojení emocionálních potřeb dětí a rodičů. Při péči o pacienty se sestry často dostávaly do situací, kdy nebyly schopny adekvátně reagovat na psychické potřeby dítěte. Jejich práce je pro ně natolik psychicky náročná, že má vliv i na jejich soukromý život.

Emoční stav dětí sestry velmi ovlivňuje, a proto je v nemocniční péči nutná přítomnost odborníka, který je schopen děti na zdravotní zákroky připravit a poskytnout jim i jejich rodinám emoční podporu. Kromě všech těchto faktorů je nezbytné také poskytovat psychologickou podporu samotným zdravotním sestrám.

Klíčová slova: dítě; emoční práce; péče o dítě; sekundární traumatizace; zdravotní sestra

\section{References}

1. Beck CT (2011). Secondary Traumatic Stress in Nurses: A Systematic Review. Arch Psychiatr Nurs 25(1): 1-10. DOI: 10.1016/j.apnu.2010.05.005.

2. Berger J, Polivka B, Smoot EA, Owens H (2015). Compassion Fatigue in Pediatric Nurses. J Pediatr Nurs 30(6): e11-e17. DOI: 10.1016/j.pedn.2015.02.005.

3. Boles J, Fraser C, Bennett K, Jones M, Dunbar J, Woodburn A, et al. (2020). The Value of Certified Child Life Specialists: Direct and Downstream Optimization of Pediatric Patient and Family Outcomes. [online] [cit. 2021-01-03]. Available from: https:// www.childlife.org/docs/default-source/the-child-life-profession/ value-of-cclss-full-report.pdf

4. Bride BE, Robinson MM, Yegidis B, Figley CR (2004). Development and Validation of the Secondary Traumatic Stress Scale. Res Soc Work Pract 14(1): 27-35. DOI: $10.1177 / 1049731503254106$.

5. Bursch B, Emerson ND, Arevian AC, Aralis H, Galuska L, Bushman J, Bulut Y (2018). Feasibility of Online Mental Wellness Self-assessment and Feedback for Pediatric and Neonatal Critical Care Nurses. J Pediatr Nurs 43: 62-68. DOI: 10.1016/j.pedn.2018.09.001.

6. Czaja AS, Moss M, Mealer M (2012). Symptoms of Posttraumatic Stress Disorder Among Pediatric Acute Care Nurses. J Pediatr Nurs 27(4): 357-365. DOI: 10.1016/j. pedn.2011.04.024.

7. da Silva RDM, Austregésilo SC, Ithamar L, de Lima LS (2017). Therapeutic play to prepare children for invasive procedures: a systematic review. J Pediatr (Rio J) 93(1): 6-16. DOI: 10.1016/j. ped.2016.06.005.

8. Drayton NA, Waddups S, Walker T (2019). Exploring distraction and the impact of a child life specialist: Perceptions from nurses in a pediatric setting. J Spec Pediatr Nurs 2019: e12242. DOI: $10.1111 /$ jspn.12242.

9. Elwood LS, Mott J, Lohr JM, Galovski TE (2011). Secondary trauma symptoms in clinicians: A critical review of the construct, specificity, and implications for trauma-focused treatment. Clin Psychol Rev 31(1): 25-36. DOI: 10.1016/j. cpr.2010.09.004.

10. Fülöp E, Devecsery Á, Hausz K, Kovács Z, Csabai M (2011). Relationship between empathy and burnout among psychiatric residents. New Medicine 4: 98-102.

11. Fülöp E, Páll N, Csabai M (2016). Amikor elfogy az energia. Kiégés és hozzá kapcsolódó jelenségek a gyógyításban. Gyermekgyógyászati Továbbképző Szemle 21(4).

12. Hárdi I (1995). A gyermek, a betegség és a kórház In: Pszichológia a betegágynál: orvos, nővér és a beteg (6th ed.) (pp. 247-259). Budapest: Medicina.

13. He H-G, Zhu L, Chan SWC, Klainin-Yobas P, Wang W (2015). The Effectiveness of Therapeutic Play Intervention in Reducing Perioperative Anxiety, Negative Behaviors, and Postoperative Pain in Children Undergoing Elective Surgery: A Systematic Review. Pain Manag Nurs 16(3): 425-439. DOI: 10.1016/j. pmn.2014.08.011.

14. Hilliard C, O’Neill M (2010). Nurses' emotional experience of caring for children with burns. J Clin Nurs 19(19-20): 2907-2915. DOI: 10.1111/j.1365-2702.2009.03177.x.

15. LeBlanc CK, Naugler K, Morrison K, Parker JA, Chambers CT (2014). Parent Perceptions and Satisfaction with Inpatient Child Life Specialist Interventions and the Role of Child Temperament. Child Health Care 43(3): 253-272. DOI: $10.1080 / 02739615.2013 .845732$.

16. Lerwick JL (2013). Psychosocial implications of pediatric surgical hospitalization. Semin Pediatr Surg 22(3): 129-133. DOI: 10.1053/j.sempedsurg.2013.04.003.

17. Lombardo B, Eyre C (2011). Compassion Fatigue: A Nurse's Primer. Online J Issues Nurs 16(1): 3. DOI: 10.3912/OJIN. Vol16No01Man03.

18. Martin HA (2017). The Power of Lidocaine, Epinephrine, and Tetracaine (LET) and a Child Life Specialist When Suturing Lacerations in Children. J Emerg Nurs 43(2): 169-170. DOI: 10.1016/j.jen.2016.12.019.

19. Mendess MG (2016). The Inpatient Children: Partnership Care and Family-centered Care. J Women's Health Care 5: 3. DOI: 10.4172/2167- 0420.1000e123. 
20. Páll N, Fülöp E (2013). Traumán átesett gyermekekkel való munka hatása a gyermekápolókra. Nővér 26(5): 3-11.

21. Perczel-Forintos D (szerk.) (2018). Kérdőívek, becslőskálák a klinikai pszichológiában. Budapest: Semmelweis Kiadó.

22. Sabo B (2011). Reflecting on the Concept of Compassion Fatigue. Online J Issues Nurs 16(1): 1. DOI: 10.3912/OJIN. Vol16No01Man01.
23. Slifer KJ (2014). A clinician's guide to helping children cope and cooperate with medical care: an applied behavioral approach. Baltimore: The John Hopkins University.

24. Zhang J, Zhu S, Du C, Zhang Y (2015). Posttraumatic stress disorder and somatic symptoms among child and adolescent survivors following the Lushan earthquake in China: A sixmonth longitudinal study. J Psychosom Res 79(2): 100-106. DOI: 10.1016/j.jpsychores.2015.06.001. 